\title{
中国湖南省新晃県トン族民家の火舗屋と骨組との関係について ON THE RELATIONSHIP BETWEEN THE FIREPLACE AND THE FRAME OF THE RURAL HOUSES OF DONG PEOPLE IN XINGHUANG COUNTY OF HUNAN PROVINCE OF CHINA
}

\author{
柳肃*, 土田充義**, 晴 永 知之*** \\ Su LIU, Mitsuyoshi TSUCHIDA and Tomoyuki HARUNAGA
}

\begin{abstract}
Dong people in Xinghuang county of Hunan province of China is the branch of Dong people in Hunan province. The life style is different from other peoples and Dong people in other place. The most famous feature is that Dong People in Xinghuang county live in the fierplace on the upper floor. There is certainly one fireplace for one family. Dong people in Xinghuan county have the habit that a few fraternal families live in one house. In this case there were a few fireplace in the same house. The frame of the rural houses was changed in order to arrange a few rooms with the fireplace. We made research on the fireplace, it's scale, it's position and the development of it's frame.
\end{abstract}

Keywords: Dong people in Xinghuang county, rural houses, fierplace, frame plane, development

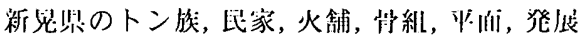

1、はじめに

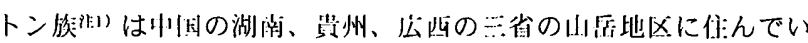

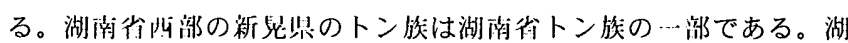

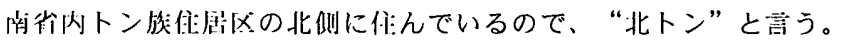

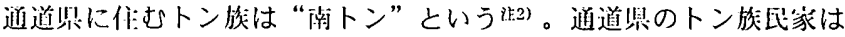
調べられているが、新它県のトン族民家はまだ調雀されていなかっ

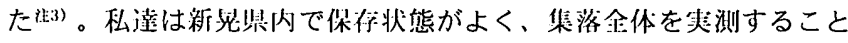
ができる規模を選んだ。それは新晃トン族自治県人民政付の役人に よる候補地から選択した。この地は北落を新面とした小高い斥で、

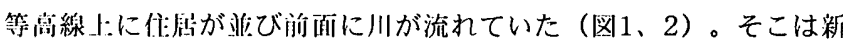

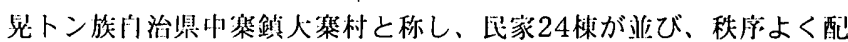

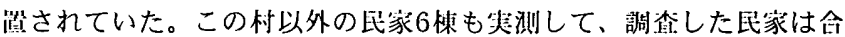

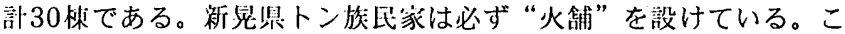

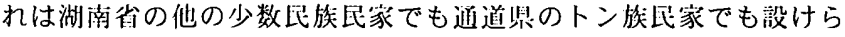

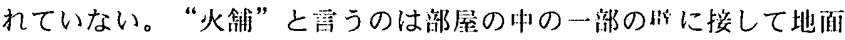

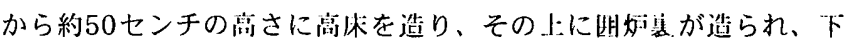

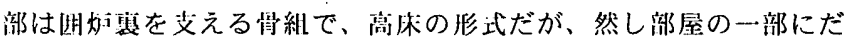

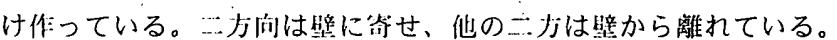
火舖下は道査や、燃料のための柴を置いている（写真1、図3）清4。

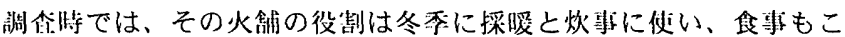

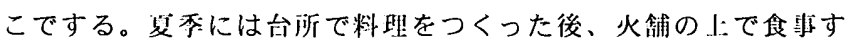

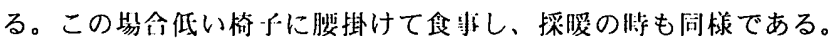
火舗で家族企員が食事し、集まるところである。火䈀は篆族の中心 で、必ず…家族に一つつの火舖がある。新晃県のトン族は絬婚した见

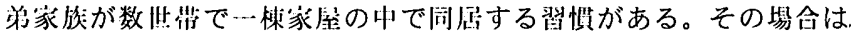

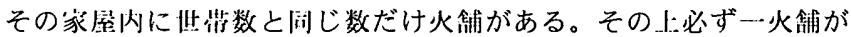

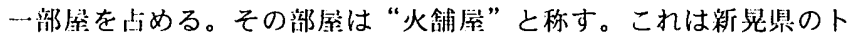
ン族民家の-番面望な特微と帣えられる。

以上の通り、トン族民家にとって重要な火舗について述べた。ま

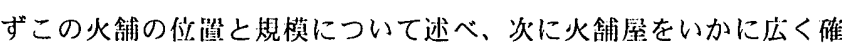
保し、壯には連続されるために綃組に変化が生じたことを明らかに する。この変化を骨組の発展と捉えその過程を考察した。

2、火舖屋の位置と規模

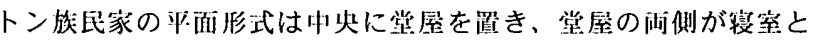

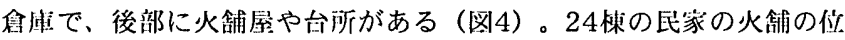
置を調べると堂剭の後少に没けることがよく分かる。後方に設ける ことができない印家7楝（図5-I の5、14、15、19、20、21、22 番）は背後に山があるため、狄い政地に建てられている。そのため 奥行が樑くできない。その結果、側洏後方に火舖を罥くことになっ

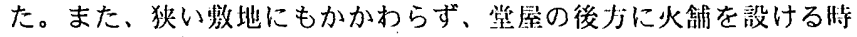

* 鹿児島大学工学部 博士後期課程 $\cdot$ 工修

** 鹿児島大学工学部 教授・工博

*** 鹿児島大学工学部 助手·工修
Doctor Course of Graduate School, Kagoshima University, M. Eng.

Prof., Department of Architecture, Faculty of Engineering, Kagoshima University, Dr. Eng.

Research Assoc., Dept. of Architecture, Faculty of Engineering, Kagoshima University, M. Eng. 


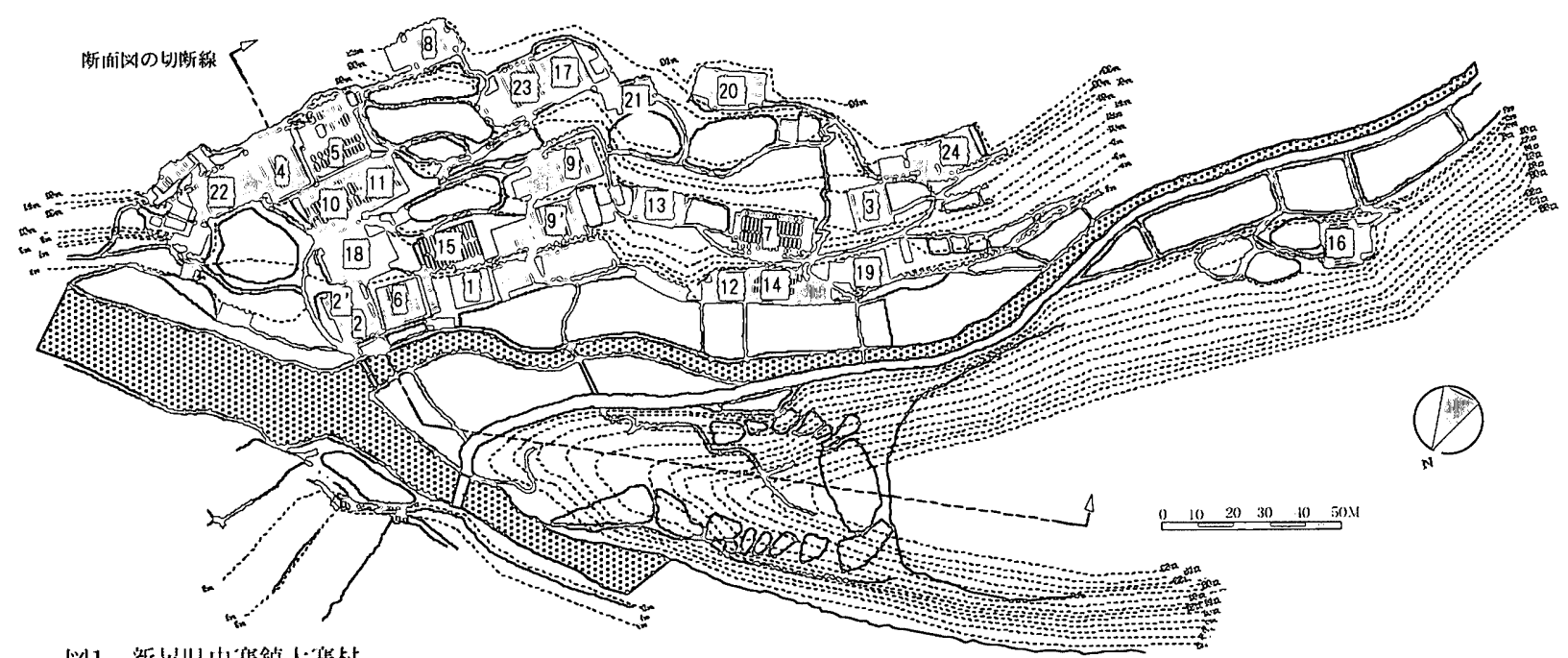

以1、激是紧中寨敛人啉村

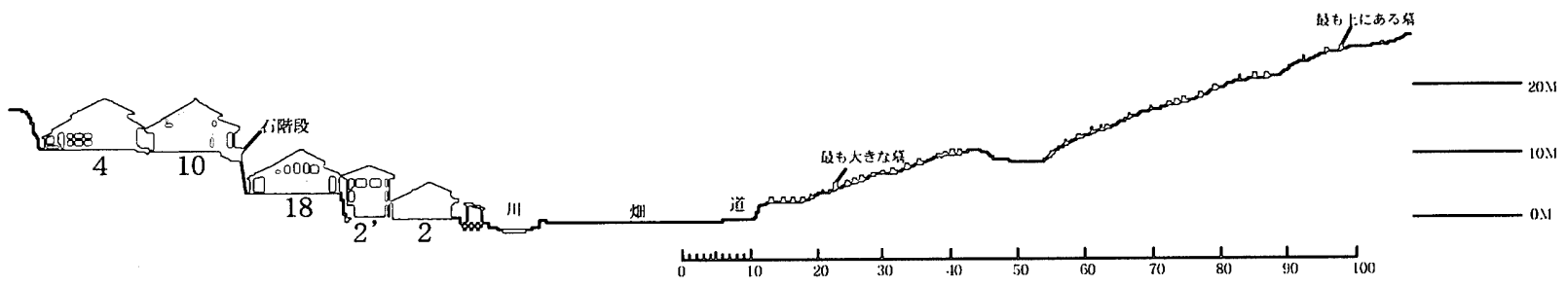

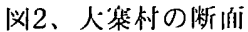

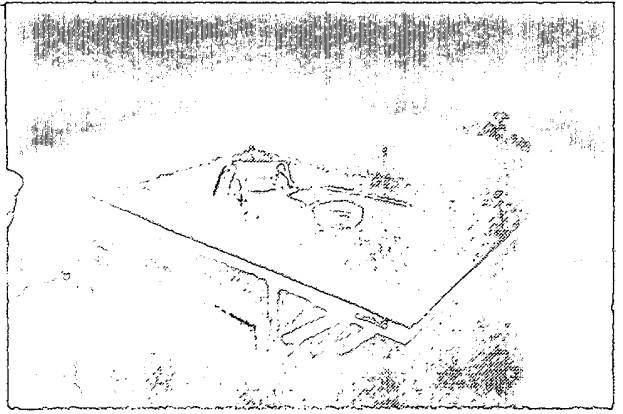

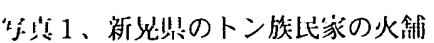

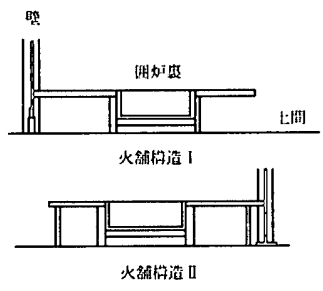

汹3、火舗の篟造

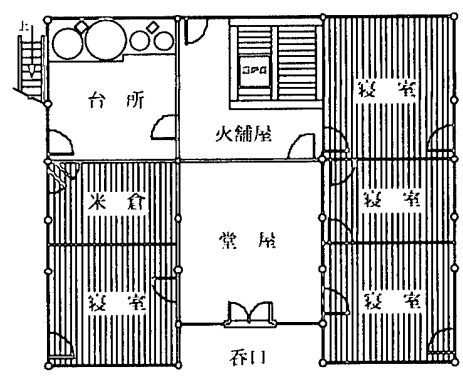

㣼4、新㐐些トン族上家の 产的形式（梁系周氏住:它）

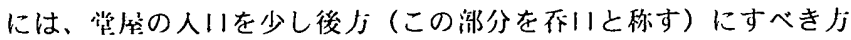

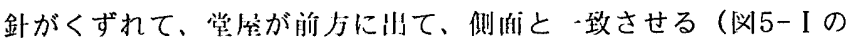

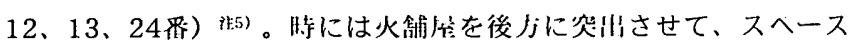

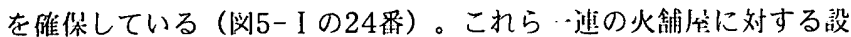

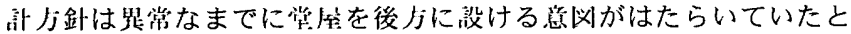

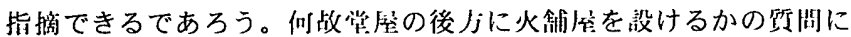
は明確に答えられなっが、火舗は単に食拈をつくるだけでなく、家

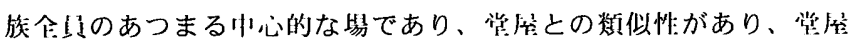
に次ぐ部特として中央に設ける必装があったのかもしれない。かま どを犊内に設けている場合もあるが（沩4）、そのかまどは後補のも ので、多くのかまどは仪設的な所に設けられていた。したがって、 作を通じて火猞を伐用していたであろう。

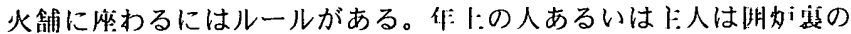

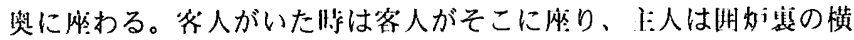

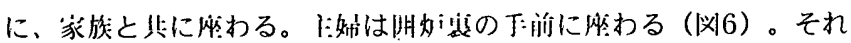

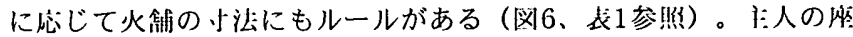
（幅g）は、婦の化（幅C）より、必ず広く、家族の訛（幅h）が昆

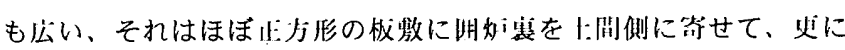

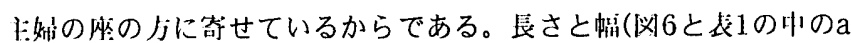

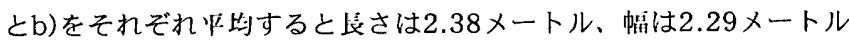
である。艮さ（a）は幅（b）より少し人きいものの、またその近も

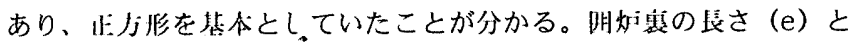

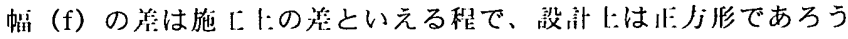
（表1）。家族の坐(h)は火舖宅の広さによるために逢いが大きい。 それから見ると火舖は、无形に近いけれども、大比なことは奥行うj

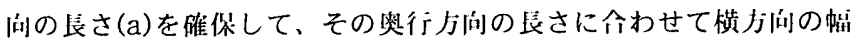
を妆めたのであろう。他に、火舖以外の上間は料理をつくるところ あるいは迎路として、定の㕕さが必要である。したがって火舒だ

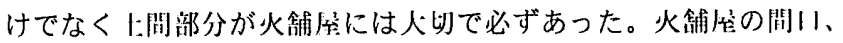

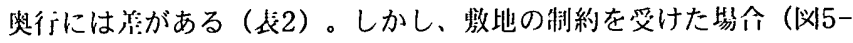



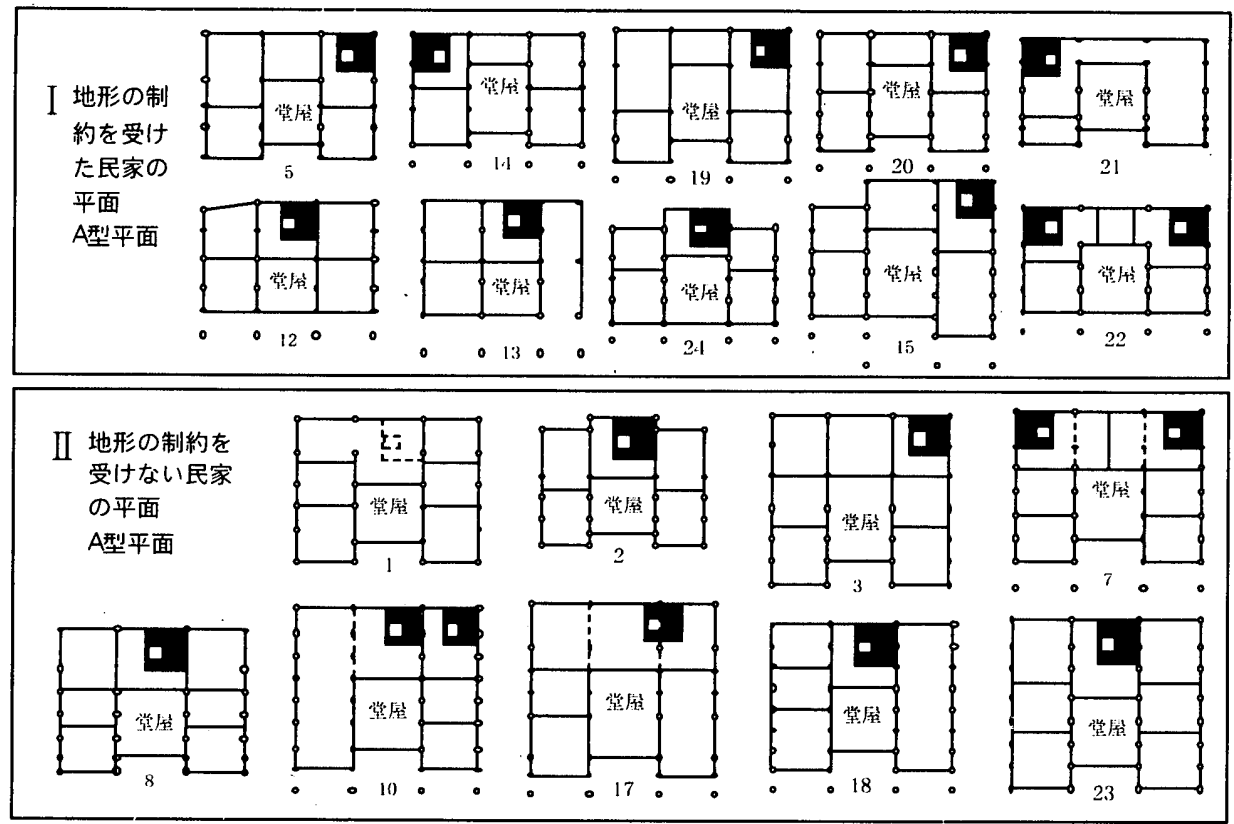
III 地形の制約を 受けない民家 の平面
B型平面
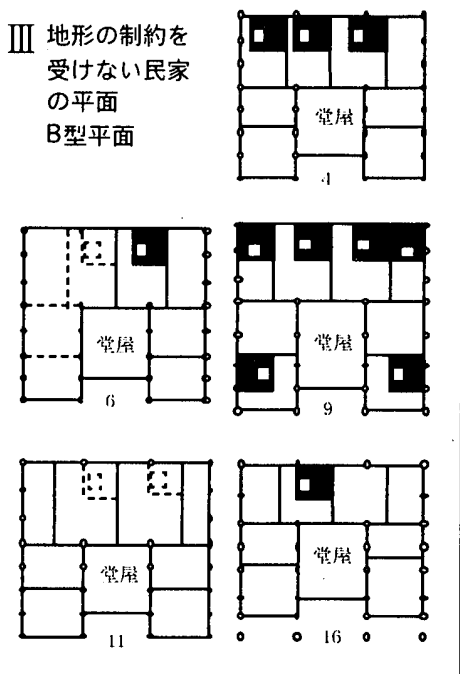

声：日䟣

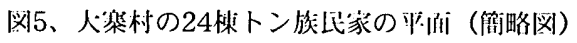

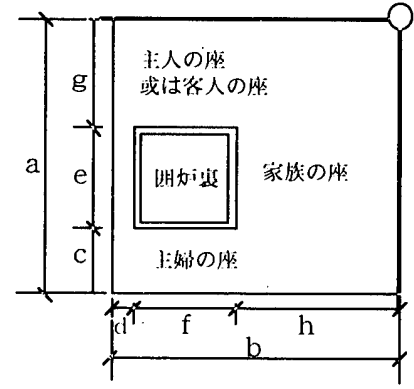

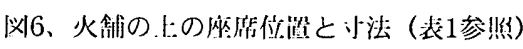

I ）でも火舖屋にまで制約を受けることはほとんどない。ただ提玉

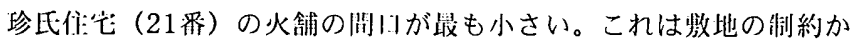
もしれない。これ以外には火猞の閪いにおいても尖行においても制

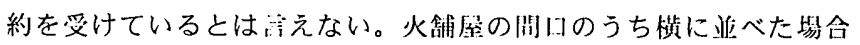
（B型活喕）は小さく、近に奥行は大きい。このことだけをまず指摘 しておこう。

\section{3、火蒁厔から見た骨組}

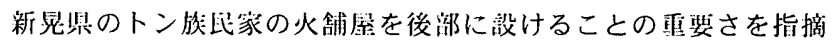
した。その骨組は必ず楝持柆があり、柱間に鿓を近し、買の上に束

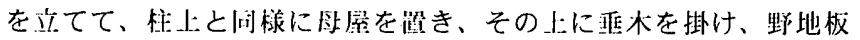

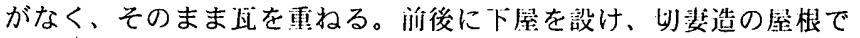
ある。後方の段差の透間から燂が出る。その下方に火舗屋がある。 その火舖屋を堂厍の後方に一列に横方间に业べることが行われた決 6)。そ机は後部部堅を分制する力法が造うので、区別するたうに“A 型平面”と“B型平洦” の一種数に分けた。つまり篮幄と後部の部屋

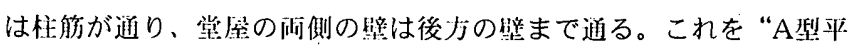
面”とする（図5-I，II）。その際教地の制約を受けるA型平面 （図5-I）と制約を受けないA型平面（図5-II）に分けてみた。そ れは火猞剭を後う兴に設ける場合と区別したいからである。次に、

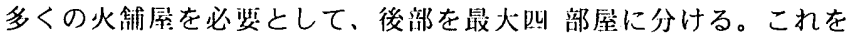

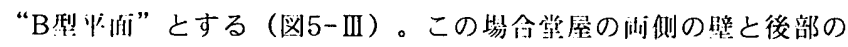

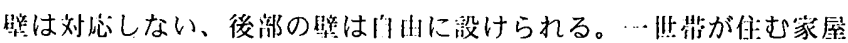

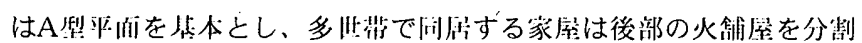

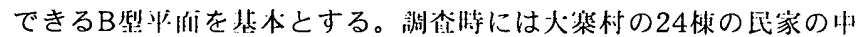

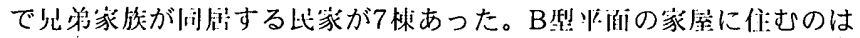

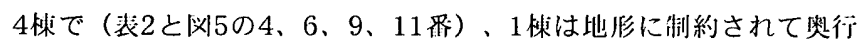

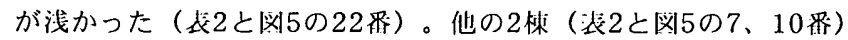

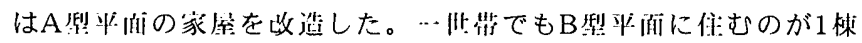

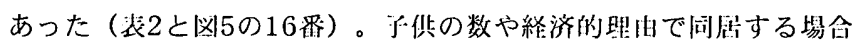

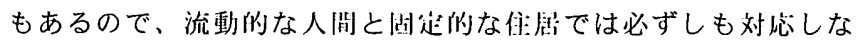

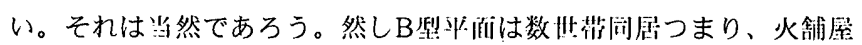
を监べることを考学して成立したことは碓かだろう。

トン族比管の骨組は中国南方比管に用いられる“呀斗式”（柱に

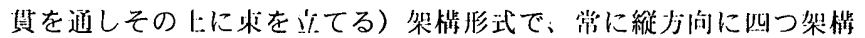

\begin{tabular}{|c|c|c|c|c|c|c|c|c|c|c|}
\hline & & & 1) & c. & 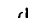 & (1) & $f$ & a & 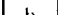 & \\
\hline 1 & 梁系㴊作往 & \multicolumn{9}{|c|}{ 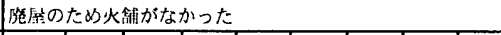 } \\
\hline 2 & 染系純任宅 & 2389 & 2390 & 541 & 160 & 891 & 899 & 957 & 1331 & 505 \\
\hline 3 & 染系淡住詑 & 2620 & & & 210 & 900 & 900 & & & 460 \\
\hline \multirow[t]{2}{*}{4} & \multirow[t]{2}{*}{ 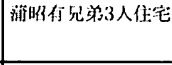 } & 2389 & 1916 & 659 & 210 & 831 & 839 & 899 & 867 & 468 \\
\hline & & 2364 & 2202 & (j27 & 210 & 890 & 895 & 847 & 1097 & 497 \\
\hline 5 & 染普速住宅 & 24100 & 2372 & 552 & 195 & 910 & 900 & 938 & 1277 & \\
\hline 6 & 梁系維兄弟2人住宅 & 2212 & 2170 & 568 & 205 & 770 & 755 & 874 & 1210 & \\
\hline 7 & 梁㹉洋见弟 2 人住宅 & 2280 & 2360 & 680 & 190 & 830 & 840 & 770 & 13330 & 550 \\
\hline 8 & 梁系阔住宅 & 2240 & 2372 & 512 & 195 & 876 & $87 \overline{5}$ & .852 & 1302 & \\
\hline 9 & 梁系兒元弟 4 人住:宅 & 2376 & 2303 & 568 & 181 & 889 & 887 & 919 & 1235 & \\
\hline 10 & 䞨必消兄弟 3 人住宅 & 2460 & 2460 & 560 & 192 & 905 & 900 & 995 & 1368 & \\
\hline 11 & 曾紀们兄弟2人住宅 & \multicolumn{9}{|c|}{ 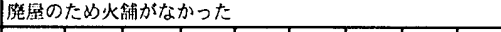 } \\
\hline 12 & 曾紀证住宅 & 2280 & 2120 & & 165 & 763. & 760 & & 1095 & 545 \\
\hline 13 & 梁系愔住宅 & 2440 & 2250 & 550 & 235 & 865 & 860 & 1025 & 1155 & \\
\hline 14 & 㑭仁礼住宅 & 24138 & 2368 & & 105 & 817 & 827 & 1516 & & \\
\hline 15 & 梁系河住宅 & 2507 & $26: 45$ & 731 & 187 & 902 & 910 & 874 & 1548 & \\
\hline 16 & 梁系解住宅 & & & & & & & & & 484 \\
\hline 17 & 粱源最住宅 & 2394 & $23 \div 2$ & $6+3$ & 125 & 840 & 849 & 911 & 1368 & \\
\hline 18 & 梁系泉传宅 & 2403 & 2338 & 616 & 229 & 771 & 841 & 1016 & 1268 & 518 \\
\hline 19 & 染系酎住宅 & 2310 & 2060 & & 150 & 845 & 860 & & 1050 & \\
\hline 20 & 粱獂東住宅 & 2430 & & & 210 & $88: 3$ & 890 & & & \\
\hline 21 & 掦玉珍住宅 & 2143 & 2020 & 417 & 145 & & & & & \\
\hline 22 & 員必狸兄私2人住宅 & 2150 & 2045 & 493 & 187 & 797 & 810 & 860 & 10.18 & \\
\hline 23 & 梁硬源倠: & 2705 & 2627 & 775 & 180 & 872 & & 1058 & & \\
\hline 24 & 染雄明住:它 & 2385 & 2378 & 560 & 160 & 900 & 900 & 920 & 1318 & \\
\hline & 证的 & 2378 & 2287 & 586 & 183 & 855 & 860 & $95 \overline{5}$ & 1228 & 503 \\
\hline
\end{tabular}




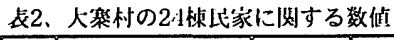

\begin{tabular}{|c|c|c|c|c|c|c|c|c|c|c|c|c|c|c|c|c|c|c|}
\hline \multirow[t]{2}{*}{ 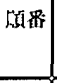 } & \multirow[t]{2}{*}{ 倠它名 } & \multirow[t]{2}{*}{ 作代 } & \multirow{2}{*}{ 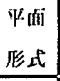 } & \multirow{2}{*}{$\begin{array}{l}\text { 蚻造 } \\
\text { 形式 }\end{array}$} & \multirow{2}{*}{ 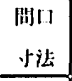 } & \multirow{2}{*}{$\begin{array}{l}\text { 奥行 } \\
\text { 小法 }\end{array}$} & \multirow{2}{*}{$\mid \begin{array}{l}\text { 尖行と䦌 } \\
11 と の \text { 比 }\end{array}$} & \multicolumn{4}{|c|}{ タイプ } & \multirow[b]{2}{*}{1} & \multirow[b]{2}{*}{$\amalg$} & \multirow[b]{2}{*}{ III } & \multirow[t]{2}{*}{ 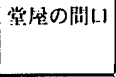 } & \multirow[t]{2}{*}{ 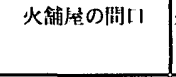 } & \multirow[t]{2}{*}{ 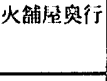 } & \multirow[t]{2}{*}{ 簿考 } \\
\hline & & & & & & & & 1 & 2 & 3 & 4 & & & & & & & \\
\hline 1 & 梁系测偖: & 150 作前 & $\Lambda$ 犁 & $A$ 型 & 10930 & 8702 & 0.8 & & 0 & & & & $\Delta$ & & 3880 & 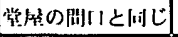 & 4122 & 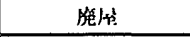 \\
\hline 2 & 架系純作宅 & 100伴的 & 八犁 & A製 & 9266 & $8 \div 13$ & 0.92 & & 0 & & & & $\triangle$ & & 3638 & $|x i|$ : & 3819 & \\
\hline 3 & 梁系淡倠沱 & 1931作: & $\therefore$ 制 & B犁 & $10520 \mid$ & 10176 & 0.97 & & & 0 & & & $\triangle$ & & 4210 & 间 $\mathrm{t}:$ & 3525 & \\
\hline 1 & 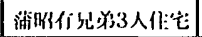 & 19;0组代 & B荊! & B利! & 11605 & 10236 & 0.88 & & & & 0 & & & $\triangle$ & 1126 & $2899 \sim 303 \overline{5}$ & .4083 & \\
\hline 5 & 染浩进作宅 & 1951年: & A刑! & A型! & $1091 \cdot 1$ & 7736 & 0.71 & & 0 & & & $\triangle$ & & & +1025 & 3414 & .13 .10 & 後部の㰾们が狄い \\
\hline 6 & 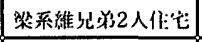 & 195. 作 & B帮! & B型! & 11820 & 10587 & 0.9 & & & & 0 & & & $\Delta$ & .1135 & $3210 \sim 3379$ & 4175 & \\
\hline 7 & 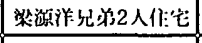 & 1960位 & 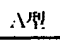 & A业 & 10530 & 10190 & 0.97 & 0 & & & & & $\Delta$ & & 3740 & 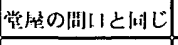 & 3320 & 浮午の中に作がある \\
\hline 8 & 梁系临儌它 & 1960作 & . 想 & B型! & 10.409 & 8958 & 0.86 & & & 0 & & & $\triangle$ & & 3686 & 洞 : : & 3683 & \\
\hline 9 & 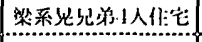 & 1961年: & B型 & $\mathrm{B}$ 些! & 12380 & 10670 & 0.86 & & & & 0 & & & $\triangle$ & 43.40 & $2 \cdot 10 \sim 3750$ & 4430 & \\
\hline 10) & 哭必消允弟3人住宅 & 1962作 & A犁 & A型 & 11668 & 11681 & 1.01 & 0 & & & & & $\triangle$ & & 4112 & 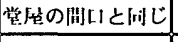 & .1670 & 激钲の中に性がある \\
\hline 11 & 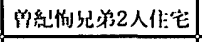 & 1962作: & B憋 & B帮 & 12269 & 10771 & 0.88 & & & & 0 & & & $\triangle$ & .4190 & $1096 \sim 4211$ & .4707 & 䇼保 \\
\hline 12 & 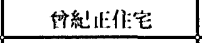 & 1965年 & A犁 & A型 & 10018 & 8.106 & 0.84 & 0 & & & & $\triangle$ & & & 3406 & 堂街の䦌いと间じ & 3325 & \\
\hline 13 & 梁系性作:它 & 1968作 & A莓! & A型 & 8960 & $87 \overline{5} 0$ & 0.98 & & 0 & & & $\triangle$ & & & 3450 & [闰 : : & 3870 & \\
\hline 1.1 & 体1:礼作:它 & 1978年 & A型 & A慗 & $106+16$ & 8177 & 0.77 & 0 & & & & $\triangle$ & & & 3852 & 3361 & 3278 & 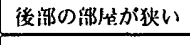 \\
\hline $1 \overline{5}$ & 然系湖件宅 & 1982年 & A型! & A型 & $11827 \mid$ & 1187.1 & 1 & & 0 & & & $\triangle$ & & & $4-101$ & 3734 & 354.9 & 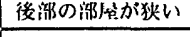 \\
\hline 16 & 梁系解住生: & 1983年 & B型 & B型 & $118: 2$ & 10668 & 0.9 & & & 0 & & & & $\Delta$ & 3980 & 3910 & 3569 & \\
\hline 17 & 染源泉隹它 & 1983作 & A型 & A犁 & 11:197| & 12.186 & 1.09 & & 0 & & & & $\Delta$ & & 4078 & 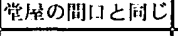 & 4551 & 部庄の中に怍がある \\
\hline 18 & 梁系的住宅 & 1983年: & $\Lambda$ 型 & A裂! & 10327 & 10.431 & 1.01 & 0 & & & & & $\triangle$ & & 3609 & [ri] I: & 4051 & \\
\hline 19 & 染系发佳它 & 1983作 & A製 & A型 & 11090 & $7.49 \bar{i}$ & 0.68 & & 0 & & & $\triangle$ & & & 3750 & 3680 & 4082 & 後部の部/於が涨い \\
\hline 20 & 梁源来倠:它 & 1983作 & A型 & A型 & 11778 & 7559 & 0.6 .4 & 0 & & & & $\Delta$ & & & 4068 & 3342 & 3472 & 後部の部他が㹟い \\
\hline 21 & 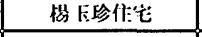 & 1983作 & 八型 & A型! & \begin{tabular}{|l|l|}
10388 \\
\end{tabular} & 6822 & 0.66 & 0 & & & & $\triangle$ & & & 3863 & 3149 & 34118 & 後部の部地が狄い \\
\hline 22 & 运必性完弟2人传宅 & 1987作 & 入敝 & A型 & $11-463$ & 8118 & 0.71 & & 0 & & & $\triangle$ & & & 4053 & $3355 \sim 40 \overline{5} 5$ & 40.48 & 後祁の部里が狄い \\
\hline 23 & 染㵀嫁价宅 & 1988作 & A型 & $A$ 犁 & 12396 & 11282 & 0.91 & 0 & & & & & $\Delta$ & & 4368 & 堂管の䦌いと同し & 4932 & \\
\hline 2.4 & 染䂺明倠宅 & 1990年: & A犁 & $A$ 犁 & 111550 & 8333 & 0.72 & 0 & & & & $\triangle$ & & & 4130 & 间上: & 3773 & \\
\hline
\end{tabular}

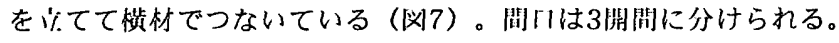

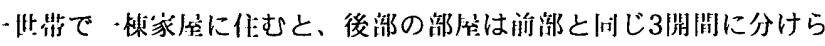
れ（A犁愐）、これを“A犁架佂”とする（図8のa）。“穿斗式”

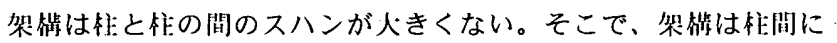
本來を伐い、時には、本束を使って、スハンを少し搪人する。然し そのスハンが火猞庢の奥行には足りない。そこで火博领の中に惟を

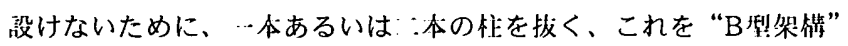

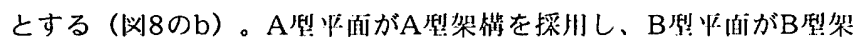

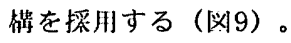

それらの架满を4つに分類して、柱を拢く過悡をたどってみる。そ れらの類型の決定的な要素は柱間のスハンである。架權で 2 A の柱間

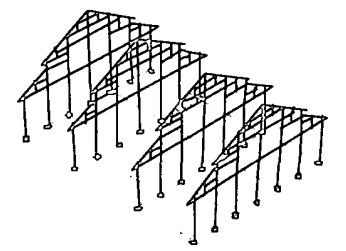

欧17、トン族比家の骨糺 。

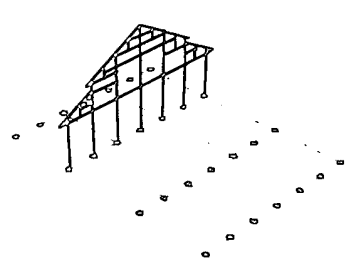

a、 $A$ 型架棉亡八型平而
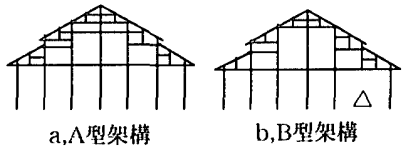

汶8、トン族し世家の :種構造形式

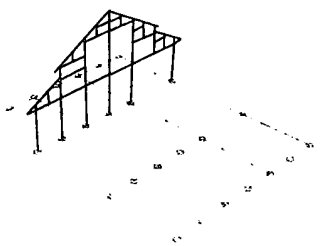

b、B型架構とB型州面目
刚9、架槛と州面との集まる
に1公束を使い、柱と柬の閶の寸法は60センチから100センチの間 で、それで柱䦌のスハンは2メートルを越えない。愔閆のスハンを㹡 大させる時 2 本束を使うことで、スハンが 2 メールを越えることが できる、然し3メートルをこえない。3メートルを越えた時は3本束を 使い、尖伱には1本柱を报くことになる。トン族比家の中で柱と往の 间にスハンが一番大きいときは 4 メートル数 トセンチにもなって、5

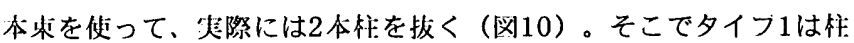
開がほほ等しくて、スハンは2メートルを越えない。タイフ2は钟の 間のスバンを昖大し、2本束を使い（灰色に鉒っている簡所）、2 メートルを越えて、3メートルを越えない。タイブ3は1本性を抜いて （埋色に叙っている筬所）、3メートルを越えて、4メートルを越え ない。タイブ4は2本柱を抜いて、4メートルを越えた。タイブ1と夕 イフ2はA型架㩐で、全てA型平面を㨙用している。タイフ3とタイブ 4はB型架梏である。然しタイブ3（柱1本を报く）の3榑の中で2棟は A筀平面で（図10と図 5 の、8番）、1楝はB型平面（网10と図 5 の 16䧽) である。タイブ4（惟2本を扳く）は全てB型平面である。夕 イフ3は完成のB犁平面への変化の過程の骨組形式と位识づけうる。

つまり、2梀は伝統的なA梨平。回を踏撉しながら、柱1本を抜いた （タイブ3）。一方1梀は柱1本を抜いただけで、B犁平俩を採用し た。これはどのように考えたらよいであろうか。トン族民家の特徽 として白由壁（往間の壁とは異なり、柱がなくとも間仕切とする 壁）を他の少数民族民家（上家族氏家、苗族民家、賥族民家）より

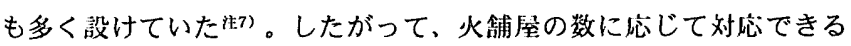
方法に末完成であるが用いた。つまりA犁平面としているのは炎舖屋

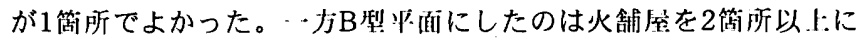
したかったから、样1本报くことで、未完成ながら火韩展の数に伈じ 


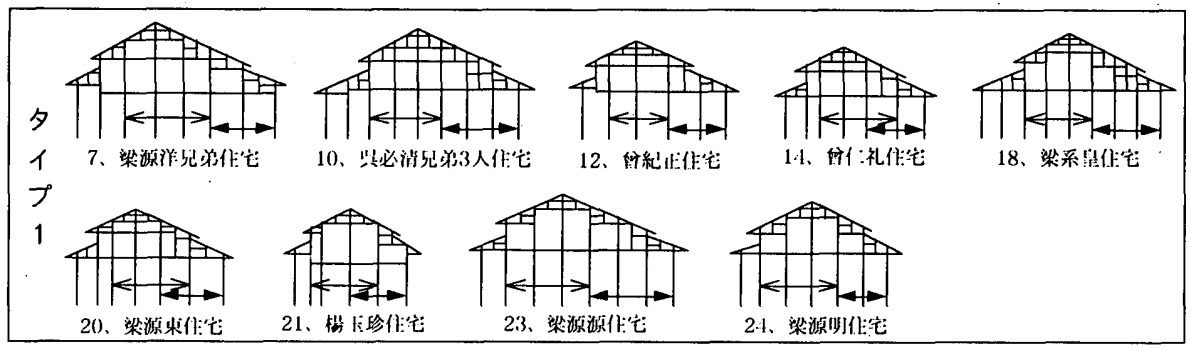

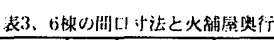

\begin{tabular}{|c|c|c|c|c|}
\hline タイフ & 番影 & 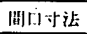 & 火補監奥行 & 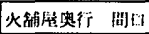 \\
\hline \multirow{3}{*}{1} & 7 & 10530 & 3320 & 0.315 \\
\hline & 12 & 10018 & 3325 & 0.33 \\
\hline & 2.1 & 11555 & 3569 & 0.326 \\
\hline \multirow{3}{*}{3} & 3 & 10520 & 3525 & 0.335 \\
\hline & 8 & 10409 & 3683 & 0.35 .1 \\
\hline & 16 & $118: 12$ & 3773 & 0.319 \\
\hline
\end{tabular}

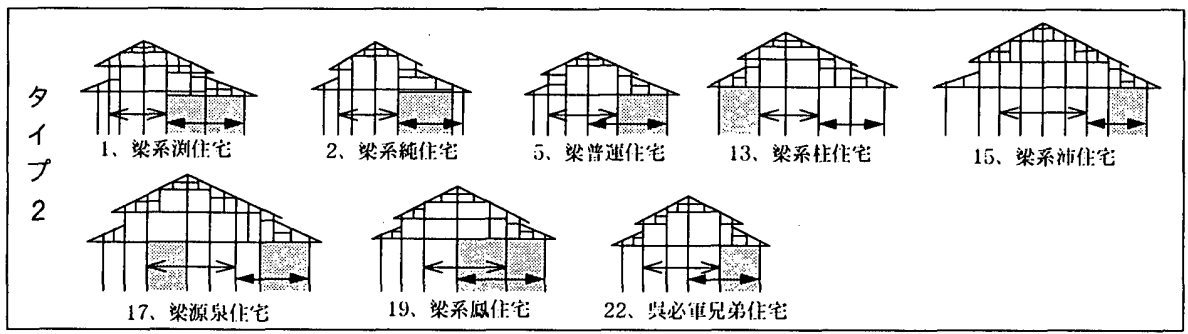

\begin{tabular}{|c|c|c|c|c|}
\hline タイフ & 舟纷 & 用川市法 & 火褌接奥行 & 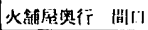 \\
\hline \multirow{3}{*}{1} & 10) & 11668 & 4670 & 0.4 \\
\hline & 18 & 103327 & 4051 & 0.392 \\
\hline & 23 & 12396 & 4932 & 0.398 \\
\hline \multirow{4}{*}{4} & 4 & 11605 & (1) 83 & 0.352 \\
\hline & 6j & 11820 & 4.175 & 0.379 \\
\hline & 9 & 12380 & 4430 & 0.358 \\
\hline & 11 & 12269 & .1707 & 0.384 \\
\hline
\end{tabular}
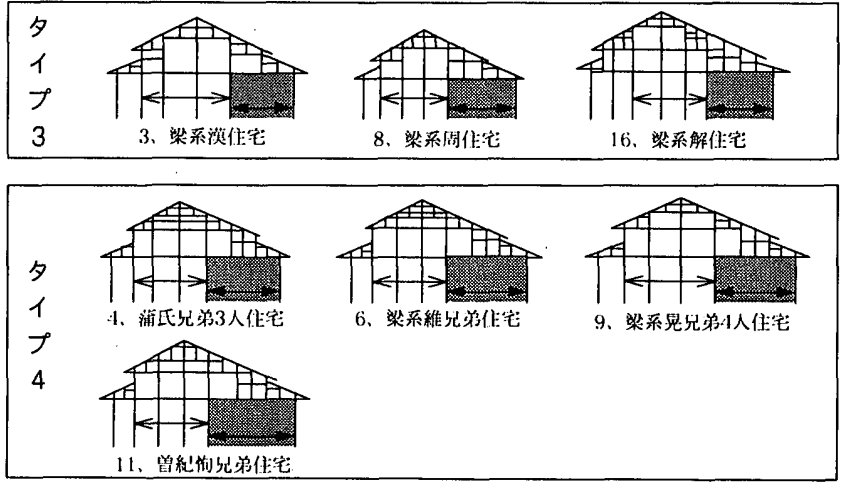

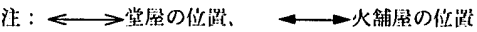

汶10、トン族民家の渋造のタイブ

て壁を自田に設けることができたからであると蓓えるであろう。夕 イブ4は完成のB等平面の能紕である。

タイプ2（スハンを少し広くし、2本来を使用）の場合、來2本を使

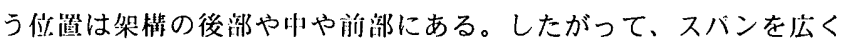
するために束を 2 本立ててる方治は火舖だけではなく、各所に設ける力 法である（図10、成色に㵑っている筬淅）。タイブ3の場合、柱を报 く位置は全て火舖屋である（図10、タイブ3）。タイブ4の場合、柱 を报く位㯰はただ火舗屋にあるだけではなく、棟持柱の前方2スバ ン、後方1スバンとなり、火舖屋の位娄がきちんとしていた（図10、 タイブ4）。これらのことから柱を減らす目的は火舖屋の中に柱を立. てないためで、広いスバンの火舖屋を碓保するだけでなく、スバ を拡大すればするほど架椯は西亚化されることを示している。

以上のことから、骨組の中で柱を拔かれてスバンを拡大するとこ ろはいつも後部で、火舗厏の分制を意図していたことが分かる。こ

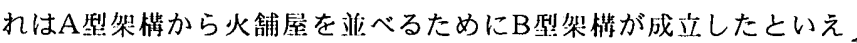

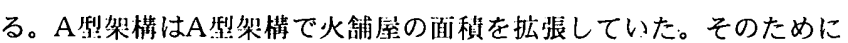
火舖屋の間口が㵊も広く尖行が最も大きい火舖层（23番）はA型架

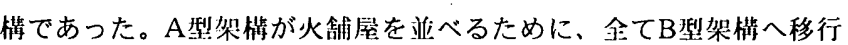
せずに、火舖屋をいくつも設けらる配怘をしながら、A型架啃にも火 舖袓の推張を行っていたのである。ここで指摘したいことは火舖剭 を监べるためにA犁架構からB犁架構が成立したということである。

4、肖縕の発展について

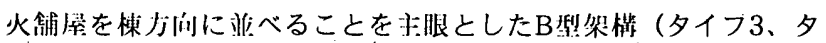

イブ）はA烈架橔（タイフ2）から成话したことを明らかにした。 ここでは能組を4種類に分数（タイフ1、タイブ2、タイブ3、タイブ 4）した各タイブが伊代と共にどのような変化をするかをたどること にする。

まずタイフ1は比較的新しい。民家棑が建ち、残った馓地に、つま

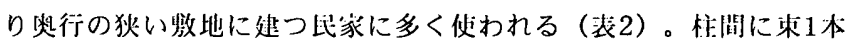

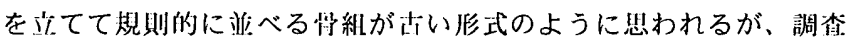
轮明では柱䦌に束2本を立て、柱䦌を少し㕕くする骨紬（タイブ2） が占い扸式であった。その少し运い柱間は火舖剭だけでなく、他の

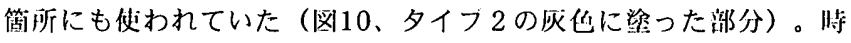
には火舖㗨に使われないこともあるので、柱閪に束2本站ててる骨組は

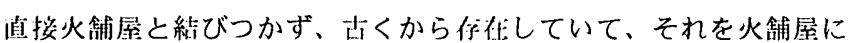
使ったということになろう。柱閒に來2本立ててた間隔では狄すぎて、 火舖屋を設けることができず、柱1本抜くタイブ3へ移行し、更に柱 2本拡くタイブ4へ移衍したといえる（図10、表2）。全て移行する ことではなく、数地の制約をうけない場㴻にタイブ1（18、23 翻）、タイブ2（17䆏）は建てられているので、むしろタイブ4の方 が建てられなくなったと言えよう。次にタイブについてA型平面と B型平耐から考察してみたい。このことは先に述べたが、年代を考虑 に入れると柱 1 本抜かれて、火舗屋を破保しても伝統的なA型平面を

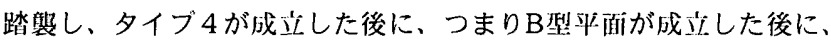
B型平面をタイブ3にも採用することになったとも考えられる。これ は少数ないけれども代代的に业べてみるといえるというだけのこと である。奉際には火舖屋が必要であれば阿端に作ることも（7番、22 番）後方に业べる（10番）こともした。骨組にとらわれずに柱を立 てたままで、火舗屋を設け（17番）たりもした。これらのことがよ り容易にできるために柱 1 本抜くことになったのであろう。これを骨 組の発展として捉えたいのである。更に柱 2 本抜いて、火哺屋を並べ ることへ発展した。

5 、民家の間口と火舖屋の奥行

火舖屋の奥行寸法が大きい場合は民家の間口は㕕い（表2）。タイ ブ4の場合は火舖屋を业代てわけでであるから、間兄を広くすること が必要であろう。そこで、闻者には関係がありそうだが、寸法値か ら备タイフをまとめると明確な数值を導き出すことができない。こ こでは柱 1 本抜くタイブ 3 と 2 本抜くタイブ4それに相はあるが夕イブ 


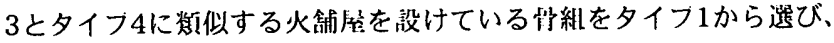
それらを比较することから䦌门と火舖屋の奥行を検到してみる。

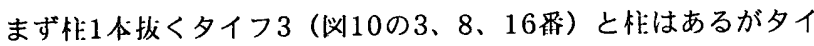

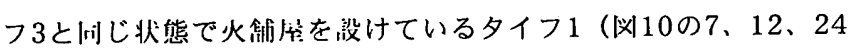

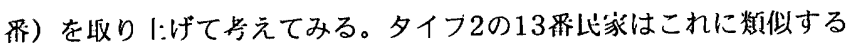

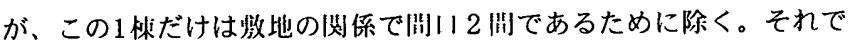

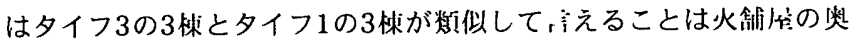
行が小さいことである（衣3）。それは校1代报いただけの店さを火

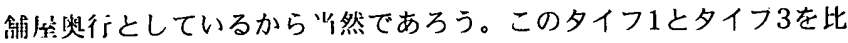

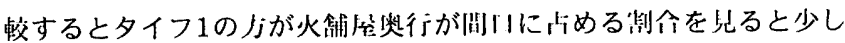

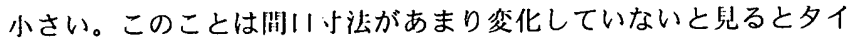

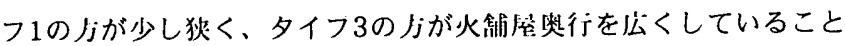
が分かる。フ フ3の16番比家が䦌门法を非常に去くした䧉けは学 片後部に火浦展を灾べる意四があったからであろう。

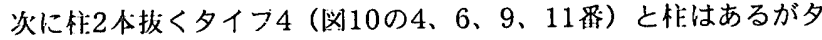
イフ4と同じ状態で火舗侄を設けているタイブ1（汹10の10、18、

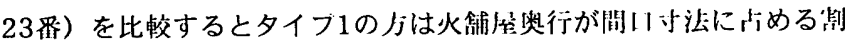

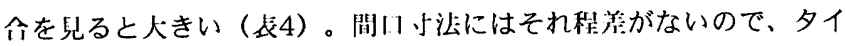

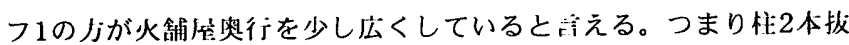

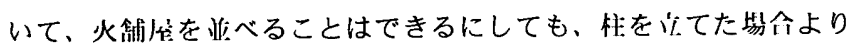
も火猞虐尖行 を人きにすることはできないことを小している。性1 本拢く场介はまだ火硧居奥行を㕕くできても、2本报くとタイフ 1 （10、18、23界）积に広くできないことはそこに险界があるのだろ う。それ敌タイブ 4 はある眝影だけに作化し、新しくなると採用さ れなくなるのかもしれない。䦌いを広くし、火铺路の奥行を大きく するのはタイフ1の尚綝のうで、このて法は伀統的なタイフ2（1、2

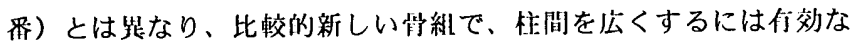
少法であった。

全体的にいえることは新しくなるに従って、骨糺（タイブ１）は

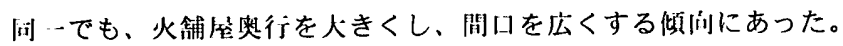
このことからタイフ 4 だけが火舖展の抬張を准めていたということ ではなく、たいぶ1も同様に進めていたことを経みとることができ る。

\section{6、結諭}

湖南省新先県のトン族は特殊な火舖の生活栚式があるので、その 火舖虐をいくつも確保するために骨組に発展があったし、平面の挔

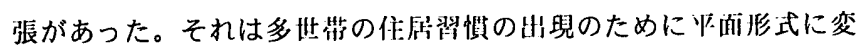
化があったと言えるだろう。その平面形式に対伈させて能組を発展 させた。作代によって、その発展の過程をたどることができた。そ れらの発展の結果、他の少数民族比家とは樭なる玵方形に近い平面 形式になったのであろう。

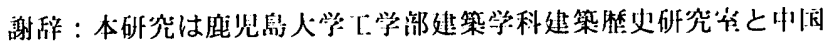

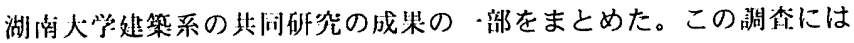

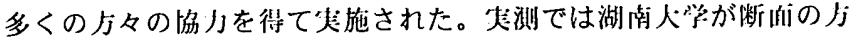

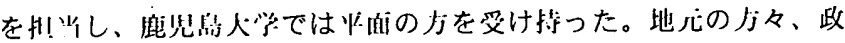

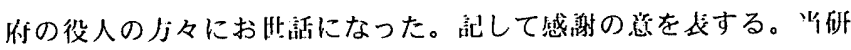

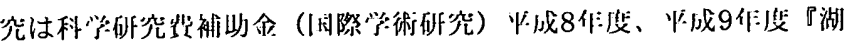

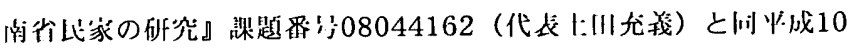

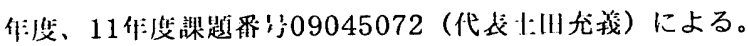

渄 :

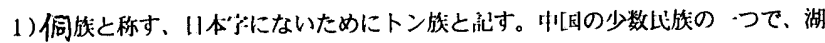

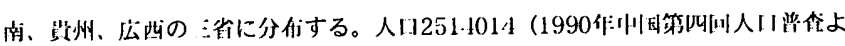
り）で、湖南少のトン族人1.1は4719026である。トン族は灲目南方少数氏民族の『古

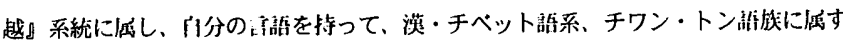

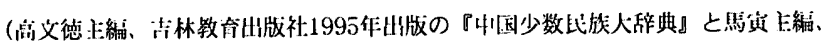

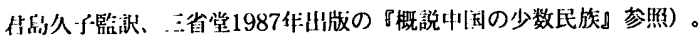

2) “北トン”と“南トン”の名は地えの名称て、、当地人民政府民族委い会の人や 地光トン族の人渤が朋ていた。

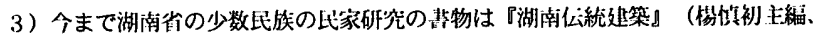

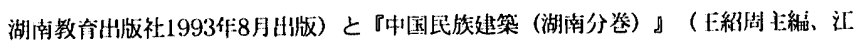

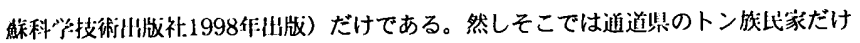

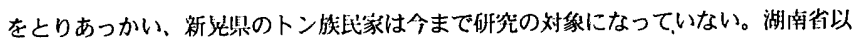

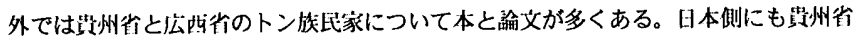
のトン旅氏䝋について綸文がある。

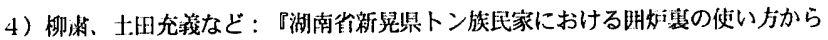

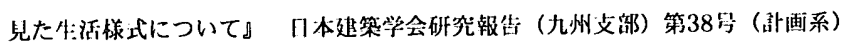

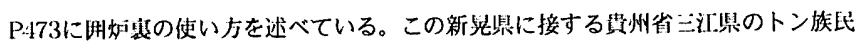

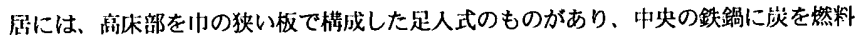
とする（日川建築NO28、26\&29貝、生活文化处NO17、30\&36頁）。

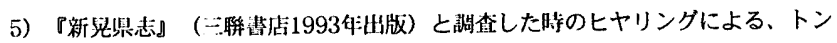

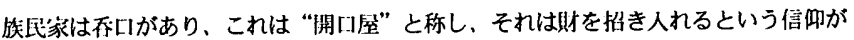
ある。そのために堂屋の人口に乔しがないのを “平口屋”と称し、造ることを避け た。

6）士由㳘義、晴永知之、米森義辰、柳肃：『中国湖南雀卜ン族民家の研究』（平 成11年9月鹿見岛大学工学部研究報告 第41管) を参照。

7）米㮏皒辰：『湖南省新兒県トン族住居の設部手法と自由璧に関する研究』 日 本建筑学会研究報告（九州支部）第39号（棓两系）P477

(2000年 5 月 8 日原稿受理, 2000 年 9 月 12 日採用決定) 